\title{
Pancasila Democratic Discourse in The Perspective of Hadith's Prophet: Ambition to be Leader
}

\author{
$1^{\text {st }}$ Tubagus Muhammad Syukron ${ }^{1}, 2^{\text {nd }}$ Hamka Hasan $^{1}, 3^{\text {rd }}$ Alvin Noor Sahab Rizal $^{1}$ \\ \{bizalrona@gmail.com ${ }^{1}$, hamkahasan@uinjkt.ac.id ${ }^{1}$, alvin.noor18@mhs.uinjkt.ac.id ${ }^{1}$ \} \\ UIN Syarif Hidayatullah, Islamic Studies Department, Jakarta, Indonesia ${ }^{1}$
}

\begin{abstract}
Indonesia with the Pancasila democratic system provides voting rights to the head of the state in the hands of the people sometimes by negatively buying people's votes. In the Prophet's hadith, asking for a more ambitious position to be a leader is prohibited. In answering the problem, the writer uses literature study by applying contextual analysis of the hadith which is based on Yusuf Qardawi's theory. The results of this study indicate that the principles of Pancasila in elections do not conflict with the results of contextual analysis of ambitious hadith to be a leader as long as there are real public reasons, bring good impact if occupied by parties that ask for positions, offers or possible vacancies that can be taken with the goal of goodness together with the ability and ability to carry out the mandate of the position properly and not in the framework of pride.
\end{abstract}

Keywords: Pancasila Democracy, Hadith, Ambition

\section{Introduction}

Leadership is one of the concepts considered very important in Islam, making it appear in the Quran and the prophet's hadith s.a.w. which discussed this. This is understandable, for leadership encompasses human life from individuals, families, even to mankind or groups. This is also supported by the fact that a leader has a right to the management of nature and social life in his realm. Muslim Mufti in his book states: "According to Harold d. Laswell and Abraham Kaplan, power is a relationship of one person or a group of people who can determine one's actions or another group in the direction of the first party".[1]

Leaders' election moment, therefore, sees to be a contest for the hearts and the support of the people of some who would be participants. How not so? With so much power, the rights and obligations of a leader, on the pretext of increasing and advancing the welfare of the people, some with all efforts and political strategies seek to make themselves a leader.

One attempt by a prospective leader to gain support in the process of running for head of state is to campaign. This is a normal process in Indonesia which is a democratic system. Because one of the principles of democracy is that of the people (government of the people) in which, in this principle, a legitimate government is one that gets the majority of the people's support through democratic electoral mechanisms[2]. As such, a candidate would even be the candidate for leadership in the country, in its mission succession to lead, should win the support of the people. This is what drives candidates to do various ways to get that support.

The campaign process, followed by the giving of its promises, is also the process of seeking support by the candidates, all part of a succession attempt to make the candidate the 
leader. All of this shows that there is an ambition to win and to be the leader that comes out of the candidates. Eventually, in view of the Prophet's hadith (peace and blessings be upon him), the ambition of a leader is forbidden. As for the hadith is as follows:

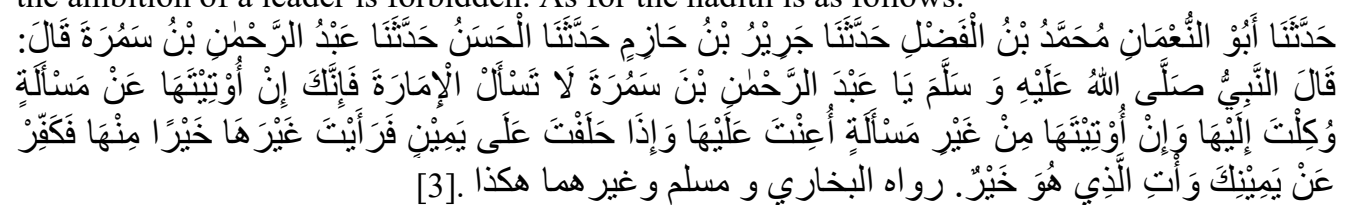

Has told us Abu Nu'man Muhammad bin Fadl, has told us Jarir bin Hazim, has told us alHasan, has told us 'Abdurrahman bin Samurah, he says: "The Prophet speaks, oh 'Abdurrahman bin Samurah, you must not ask for office, for if you are given (office) for asking, you will be deposed, and if you are given by not asking, you will be helped, and if you take an oath, then you see something better, pay your vow and do better"' (Bukhari, Muslim and other).

This hadith showed that asking for a position, that person would be abandoned. alMuhallab says: "the ambition of office is the instigation of human warfare until bloodshed, confiscation of wealth, forfeiture of honor and disfigureation of the earth's surface" [4]. It appears that al-Muhallab's assertion did occur in the elections during the campaign process (for example: the black campaign).

This hadith is not textually about ambitious. However, ambition was an alternative in the hadith's understanding. This is supported by a hadith as meaningful as this:

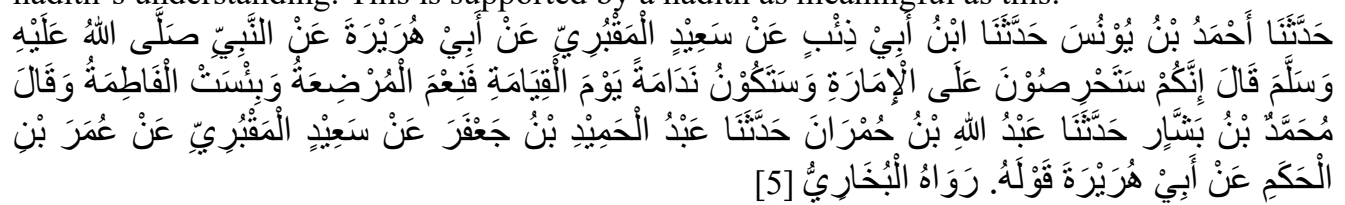

Has told us Ahmad bin Yunus, has told us Ibn Abi Dhi`b from Sa'id al-Maqburi from Abu Hurairah from the Prophet. He said: "Surely you have a ambition to fill your post, and it will be a regret at the end of the day, as good as the breast-feeding and bad as the weaning". Muhammad bin Basshar says, "Abdullah bin Humran has told us, "Abdulhamid told us from Sa'id al-Maqburi from 'Umar bin al-Hakam, from his words” (al-Bukhari).

The hadith contained the word "حَنَحْرِ صُوْنَ" drawn from the root of the word "حِنَ" meaning "الجَشَعَ وَالبُخل as meaning avarice, greed, stinginess [6]. In addition, Ibn Hajr al"Asqalani gives an explanation or "sharh" to the hadiths above leads to ambitious significance, coupled with several sources which the author finds, much of the word ambition in the use of the hadith above. And so the author uses these diction ambition to do contextual research of the hadiths above. From the foregoing, there is a difference between the context of Indonesia's current electoral system and the hadith. It is one of the problems in which a hadith is judged as "sahih" runs counter to an election system in Indonesia. Solutions and solutions need to be achieved, not to cause sustainable conflict, since Indonesia is the world's largest islamic nation. 


\section{Research Methods}

In this research, reviewed from its place, the author uses library methods. Because the focus of this research is the prophet's hadith as the key to the problem, the primary source of the research is the hadith of the Prophet and because of its many hadith on this, the writer takes a sample of the hadith presented by bukhari with more powerful quality (sahih). And so the original test process does not have to be done. As nawawi thought in at-taqrib wa at-taysir li ma'rifah sunan al-bashir an-nadhir, that the book of al-Sahih al-Bukhari is the most correct after the Quran [7].

In doing this research, the author uses a content analysis approach. The content analysis approach is a research technique for drawing conclusions by systematically and objectively identifying specific characteristics of a text [8]. In this regard, author analyzes hadiths ambition to be a leader by using the contextual theory of hadith based on Yusuf Qardawi's theory in his book al-Madkhal li Dirasah as-Sunnah an-Nabawiyah.

\section{The Principles of Pancasila Democracy}

Moving away from the central concept of Pancasila Democracy which explicit sounds of greed led by wisdom in the representation or representatives (the 4th pancasila), pancasila's democracy placed the wisdom of discretion as the basis in the execution of democracy [9].

The Indonesian independence committee (PPKI) instead of using the Greek word "democracy", it uses the word "kerakyatan"(English: populist) that is truly Indonesian. The two words have a corresponding meaning: democracy has the same meaning as populist. This can be proven by tracking the meaning of the word populist as follows. Populist is an adjective that means a quality about the people. Everything is said of the people when it truly reflects the truth of the people. To truly reflect the people, it must come from the people, be run by the people, and be directed toward the people. The condition by which Abraham Lincoln called democracy. Etymology, democracy is not Indonesian, it is Greek. In Indonesian, the language of democracy is "kerakyatan" or populist. So "kerakyatan" (English: populist) is the Indonesian word for democracy [10].

That the only way to include the people in determining future leaders and representatives in parliament is to convene a general election. This is regarded by almost all the countries that hold the democratic system as the most effective and most feasible way to proceed because it can include all its people directly in the Democratic Party each period of the leadership transition as a reflection of the democratic system as well as in Indonesia which also identifies itself as a democratic state [11].

Election is the democratic means by which they can be determined from which they are entitled to perform their duties in the state, legislative and or executive political institutions. In the elections, people vote for a trusted figure who will fill legislative and or executive positions. Election administration is given to the people who have met the requirements to vote, freely and in secret, dropping their vote only on figures judged according to their aspirations. Surely no aspirations can be found, out of so many votes that those who have the most votes are named the victor for representing the will of the majority. [12].

Pancasila the fourth article of populist led by wisdom in the community of representatives is represented in the politics of the state.The symbol of bull is the same social animal as that of 
a social person. Where in decision making is taken together or in deliberation, cooperation and family in which these values are defined by distinctive values and the lives of the Indonesian people reflected in the basic values of the country. According to Syahriani for the meaning of the fourth point pancasila is:

- The high value that puts the needs of the state and society ahead of self and class;

- The high value that donot impose their will on others;

- The high value of a culturally oriented decision making;

- The high value sit in council until the completion of the agreement word that is overcome by a kinship spirit [13].

Further, within the populist points, the value of democracy must be carried out implicitly in our national lives. For the democratic values contained in those populist points are among them was to trust representatives entrusted with the convergence [14].

Especially the quality of elections need the role of the political party to be mature which the cadres are educated to become individuals with credibility, integrity and accountability and poise as well as popularity due to merit, dedication and loyalty to nations and countries [15]. Thus the purpose of the holding of a really optional festival of people sovereignty was occupied because of the appropriateness of choice for human capacity to be better than others who were not elected.

Thus, pancasila democracy, in principle was called for an election. In doing so, pancasila's democracy also wants candidates whether they come from the party or not. All of that means a people's voting competition for a certain position in the country.

\section{Hadiths Ambition to be a Leader}

In this research, the author turned the two hadiths into primary objects. Both the hadith are:

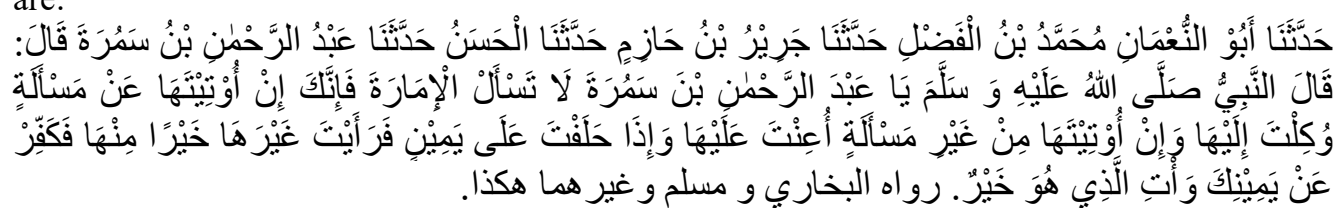

and :

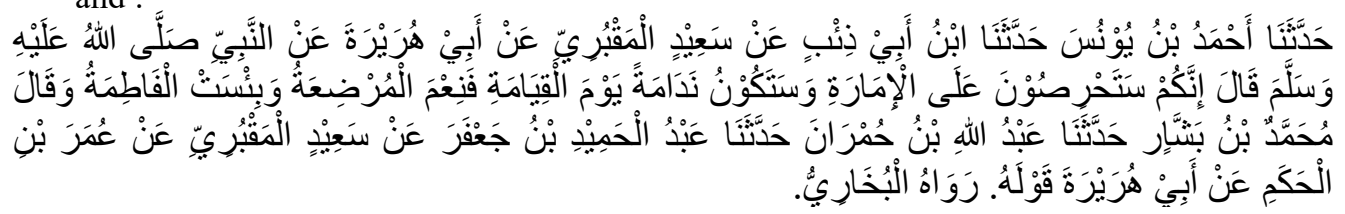

In the first hadith, the ambition of office is understood to be that asking for something related to office is makruh (disapproved). The implication of this office is government, court, finance, and so on. And he who is ambitious for such shall not be helped. As for the second hadith, it is understandable that the Prophet announced the coming information of an ambitious entrance and the highest office of khilafah as well as a lower rank. Anyone not doing as he was supposed to be doing so would be regretful at the end of the world. As wellfed as the world is and as bad-mouthed as it is post-mortem. Someone to take into account his actions in the world (yaum al-qiyamah). 


\section{Contextual Analysis of Hadith Ambition to be the Leader}

To find out the worthiness of a hadith being made into rain, criticism of the matn of hadith needed[16]. As for this research, author is applying contextual methods. Hadiths of ambition to a position is more correctly understood contextually. For there are strong instructions that require that the hadiths be understood and applied, not as relevant as they are. The powerful clue to the presence of the hadith is bound to a certain place and time, and from a specific cause contained in the hadith, which is considered to be its common tenacity. Thus, the ambitions of these to be temporal and local leaders are necessary for contextual understanding to achieve complete meaning.

Besides, this hadith is strictly government issue. In other words, this hadith was pronounced by the Prophet with the capacity of head of state and community leader, not as Rasulullah. This, if coupled with Syuhudi Ismail's theory, gives opportunity and encouragement to reason to bring goodness to the basis of general religious instruction. Thus the cens are persistent/zanni [17]. From such exposions, it is clear that the hadiths of ambitions for leadership are now worth remembering with context.

In this regard, the author will point to matn's criticism of the two hadiths that became objects of this study by anchored to the theory of Yusuf Qardawi. In the theory of Yusuf Qardawi, there are eight criteria of understanding the hadiths. But the author uses only six criteria, since two other criteria, the locution analysis and magic, are considered irrelevant to the hadiths discussed[18].

\subsection{Understanding as-sunnah according to the instructions of the Quran}

The hadiths discussed above correspond to the two verses of the Quran, the surah of Yusuf verse 55, and the surah Sad verse 35 [19]. Here is the scripture in question:

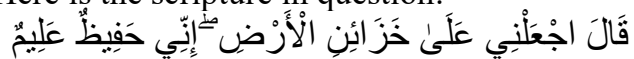

"He (Yusuf) says: 'Take me as treasurer of the country (Egypt); Truly I am a man of science again"”. And

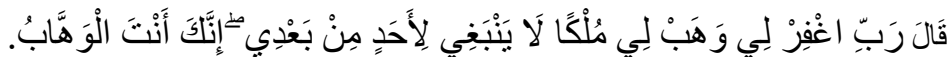

“And he (Sulaiman) said: 'O my Lord, forgive me, and grant me the kingdom that none before me possess, for You are the very giver"'.

In this surah of Yusuf, the 55th verse, it is evident that the prophet Yusuf called upon the king of Egypt to be placed as treasurer. In understanding the text, Sayyid Qutb defended, that the prophet Yusuf did not extolate the king in order to devote himself to him. Rather, the prophet Yusuf was limited to asking for a position he believed he could solve a future crisis that he vowed to hold on to the king's dream. This was done by the prophet Yusuf because he was truly an expert and was firm in his ability to resolve the crisis and not for his own benefit by taking a chance. On that occasion, the prophet Yusuf felt that he was the most deserving of the position [20].

On the other hand, the Prophet Yusuf did not intentionally ask the king for office. This proved with the fifty-fourth verse of the surah that read:

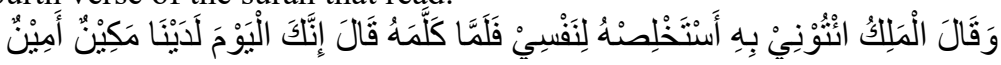

“And the king decreed, 'bring him unto me that I may choose him for myself alone'. So when he has spoken with him, he says: 'you today (at our side) are a man of high station again trusted"". 
Professor M. Quraish Shihab in Tafsir al-Misbah says that in the fifty-fourth verse it is the king's decree without wavering to take the Prophet Yusuf as his counselor and servant in turn the wheels of government. Based on this information, Professor M. Quraish Shihab explained as follows, that the demand for office taken by the Prophet Yusuf did not stand out against religious morals because as it stands to be said, the Prophet Yusuf was offered first by the king to help him in various areas. The offer died on, but the Prophet Yusuf chose a specific duty. So he requested that the assignment be limited to his specialty, the treasury of the state [21].

On the surah of yusuf's fifty-fifth verse above, still on the matter of asking for office,

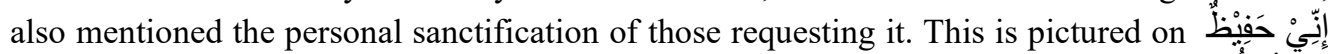

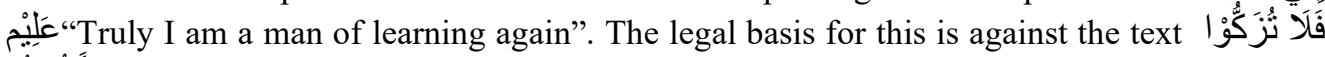
(an-Najm: 32) "then, do not say yourself chaste". However, there is a need for this, while others do not know their strengths and abilities [22].

Sayyid Qutb and M. Quraish Shihab agree on this, the fifty-fifth verse of Yusuf's surah being the basis for his running to occupy a particular office by campaigning for himself. Further, M. Quraish Shihab limit, if his motivation is for the benefit of the community and if it feels capable to occupy that position. On the other hand, Sayyid Qutb has also restricted, if not to a society that has a perfectly islamic growth, structure, and commitment [23]. This was the author in accordance with the circumstances of the prophet Yusuf for the office and for the sanctification of himself (campaign) to Egypt's king whose people had no perfect growth, structure, and commitment to the teachings of the Lord.

Furthermore, in the surah of Sad verse 35, the prophet Sulaiman asks of God for the given of a kingdom that no man can claim after that. This indicates that the prophet Sulaiman demanded world power. This was permissible for a governmental scheme and for the governance of society in order to establish god's laws. This means that those capable of guarding god's great the syi'ars are allowed. This is understood by the impossibility of the prophet Sulaiman as a prophet asks the world and love it. Therefore, God gave it on the basis of his will and his knowledge that the prophet Sulaiman was his chosen servant [24].

The interpretation of the two verses suggests the Quran as applying for position. With that hint, the hadith is about asking for an adjusted position and should not conflict with the Quran's direction. The adjustment of the hadiths to the instructions referred to in the two verses would be a First, perhaps asking for position if the party calling for the office was not simply to serve its superior rather than for its own interests or class, but had real reasons for common good. Second, may ask for an office that will have a good effect if it is occupied by those requesting it. Third, the requirement of an office must come not only from the applicant but also from the applicant's request or possibility of an offer that could be taken up for public good. Fourth, it is allowed to apply to an office if the other party is not familiar with the surplus of the applicant or if the motivation is for the common good or if the office is in an environment that does not agree or is not committed to applying islamic laws, habits and structures. Fifth, the appeal of office is allowed if accompanied by the ability and ability to hold the post well and not in an effort to boast. Thus, if in the process of requesting an office does not contain all five conditions, then ask for Allah.

\subsection{Add up the hadiths intertwined in the same theme}

To gain a clearer understanding in the absence of opposition, the same themed hadiths must be mounted [25]. In compiling the hadiths on the subject of ambition to be a leader, 


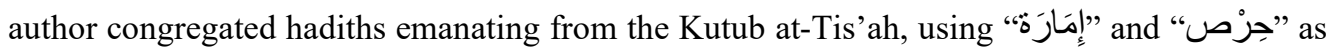
the key word to search for al-Mu'jam al-Mufahras li Alfaz al-Hadith an-Nabawi by Arnold John Wensinck. In addition, the writer also sought the basis of these themes relating to the leadership of the Kutub at-Tis'ah.

The author found the hadiths that coincided with the two hadiths which were researched. Among them are the hadiths that share a slightly different meaning with the slightly different matn editor in the history of Abu Daud in the book of Sunan Abi Daud topic of Imarah chapter twenty-second number 2540 which reads:

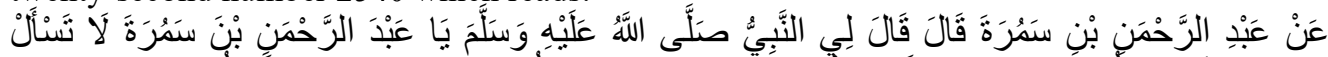

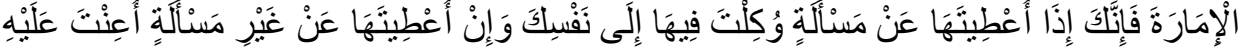

From 'Abdurrahman bin Samurah, he says: "The Prophet speaks, hai"Abdurrahman bin Samurah, you must not ask for office, for if you are given (office) for asking, you will be deposed, and if you are given by not asking, you will be helped"' (Abu Daud).

In addition to the hadith, there is coincided by Ahmad in his book Musnad Ahmad volume second of page 448, number 9790:

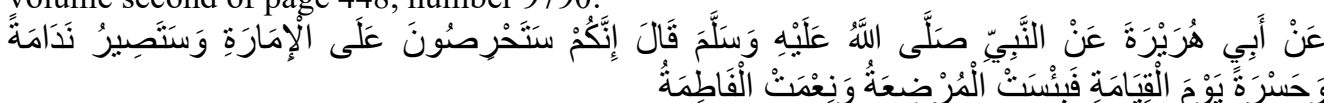

From Abu Hurairah from the Prophet. He said: "Surely you have a ambition to fill your post, and it will be a regret at the end of the day, as good as the breast-feeding and bad as the weaning" (Ahmad).

Even so, the author found two hadiths by muslim who provide a further description of the hadiths above. Even so, the author discovered two hadits same theme, both delivered by Muslim who provide further information on the hadiths above. The two hadiths is:

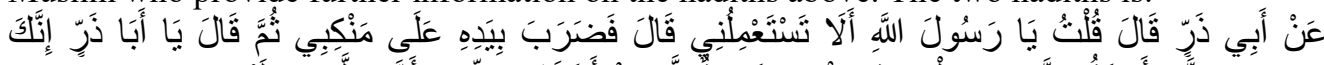

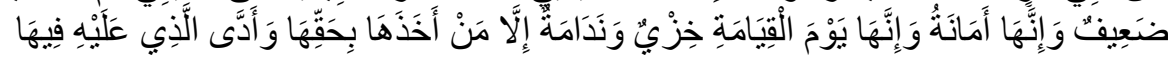

From Abu Dharr, he said, "I say, 'O Messenger of God, do not make me an officer?" AbuDhar said, "Then he patted my shoulders with his hands as he said, 'dear Abu Dharr, you are weak (to hold rank when addressing a post). At the end of the day he is a humiliation and a regret, except for those taking it by right and performing right duties"” (Muslim). And

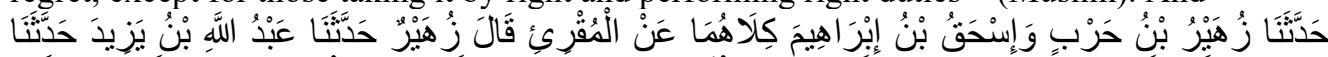

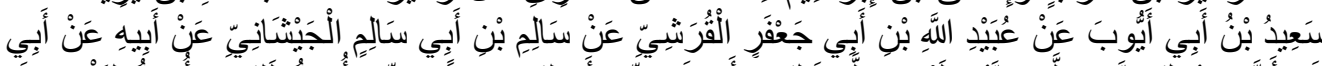

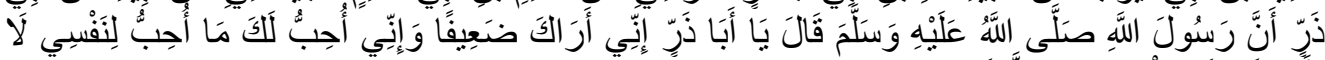

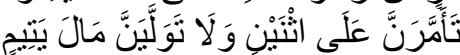

From AbuDharr, that Rasulullah said: “Oh Abu Dharr, I really see you as weak, and I want for you as I want for me. Do not you be the leader among two and do not we conquer the orphan's fortune" (Muslim).

In this hadith according to Daruqutni is updated on 'Ubaidullah bin AbuJa'far. However, Daruqutni does not decide anything about the status of the hadith, for the hadith is sahih in sanad and matn [26].

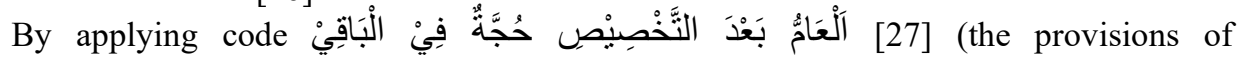
'amm/common after the existence of mukhassis/specializing still apply to the remnants of the provisions), so the hadiths of ambition for a leader are understandable in denying him office and not helping him one who asks him for office in his office and inflicts loss on the coming day of judgment, all of which are especially for the incapable of holding that office because the office is a legacy. 


\subsection{Incorporation or weighting or copieswhich (apparently) are contradictory}

There is a seemingly contradictory hadith which is this:

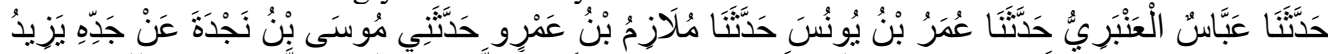

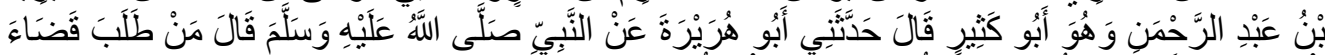

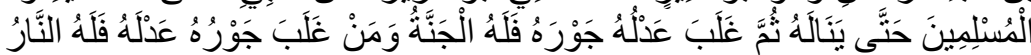

"Has told us 'Abbas al-'Anbari has told us 'Umar bin Yunus has told us Mulazim bin 'Amr has told me Musa bin Najdah from his grandfather Yazid bin 'Abdurrahman, he is Abu Kathir, he said: "has told me that Abu Hurairah from the Prophet, he has said: "whoever wants to be a judge, and then his justice beats his tyranny to him heaven, and he who is in his iniquity overcomes his justice to hell"'.

Regarding the contradictory hadiths at this research, the hadith is judged da'if because Musa bin Najdah is a person who is majhul [28]. In addition, the author found none of the hadith behind the hadith of Abu Daud. Therefore, the hadith of Abu Daud is judged by munkar because this hadith is nestled by a person who is da'if and is opposed to the hadith which is directed by rawi who is thiqah. Plus this hadith is not found a supporter, while the previous hadith of Bukhari Muslim had many supporter. So the hadith al-Bukhari as meaning hadith ma'ruf [29]. Thus, such contradictory hadiths cannot be compromised.

Even so, al-Hafiz Ibn Hajar al-'Asqalani in the book of Fath al-Bari committed a aljam' wa at-taufiq or compromising in response to the contradictory hadith between the hadith of al-Bukhari and Abu Daud. As a result, the absence of help to the hadith of al-Bukhari had no consequence in his justice in the requested office.

The other hadith is:

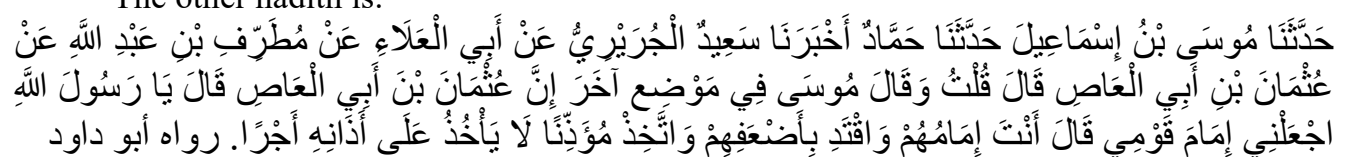

Has told us Musa bin Isma'il has told us Hammad has advised us Sa'id al-Jurairi from Abu al-'Ala' from Mutarrif bin 'Abdullah from 'Uthman bin Abi al-'Ash says: "I once said, 'O Rasulullah, take me as a priest of my people!' He says, 'you are their priests, and take into consideration the weakest of them (when measuring his prayer), and take the muadhin of the man that does not take his wages" (Abu Daud, al-Nasa 'i and Ahmad).

Thus, the contradictory hadith could be done by applying the al-jam' wa at-taufiq. Applying the method, the author does "ta 'wil" against the contradictory hadith [30]. As for the result is that it was true in the hadith of Abu Daud, 'Uthman bin Abi al-'As requested a position which was a prayer priest of his people to the Prophet, and then the Prophet granted it. If we see the profile of 'Uthman bin Abi al-'As, it is known that he was the man whom the Prophet believed to be the leader of the delegates when they had surrendered themselves to the islamic faith sent by Banu Thaqif to meet with the Prophet for negotiations. In addition, he was also a man who was very keen to study the Quran to the Prophet, even if the Prophet was sleeping, he studied to AbuBakr. He was also a man of great significance to his people during the apostasy. He was the one who said and convinced his people not to apostatize when the Prophet died. And so his people went back to Islam [31]. He was also entrusted with the Prophet to work on Taif[32].

Thus the result of the "takwil" of the contradictory hadith, viewing that the "Uthman bin Abi al-'As is a person who did acquire a trust early from the Prophet was necessarily based on his quality and credibility that the Prophet received his request to make him a priest. In addition, it is acceptable for good [33]. 


\subsection{Understanding the hadith takes into account the background, the circumstances and conditions as pronounced, and the purpose}

The background of hadiths of ambition to be a leader is said to be seen in the hadiths itself. Thus, the background of hadiths the ambition to fill an office is the request of the office coming from a stranger and/or coming from a man known to be weak in holding the office in question. Nevertheless, this temporary conclusion needs to be adjusted to the condition, the circumstances and the purpose of the hadith.

As for the conditions and situations at the time of hadith being spoken, in looking at hadith's forbidding the office, there were found to be two close friends of the prophet who delivered the hadiths by specifically speaking directly to both 'Abdurrahman bin Samurah and Abu Dhar purchased. Whereas the hadith in which the prophet fulfils the request of office is delivered by 'Uthman bin Abi al-'As.

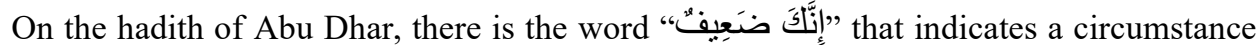
the Prophet was talking to a person who was considered weak by him. Whereas on the hadith of 'Uthman bin Abi al-'As, the Prophet accepted the request. As already noted, that 'Uthman bin Abi al-'As would be someone who had been entrusted from the start by the Prophet as a leader. It is therefore understandable that the Prophet was speaking to someone whom he was deemed credible. Later on the 'Abdurrahman bin Samurah' hadith, found a word used by the prophet by the second person (khitab) that refers to an 'Abdurrahman bin Samurah. By looking at the hadith of AbuDharr, it is understandable that the condition of hadith of 'Abdurrahman bin Samurah was a Prophet speaking to a man who was considered weak by him.

As for the purpose of the hadits being said, by seeing the hadits ab $\bar{u}$ those arr is the word "وَإِنَّهَا أَمَانَةُُ، which means the position or leadership is the amanah, even a leader or persons in a position should be filled by credible persons in the performance of his or her duty.

Thus, from the description of the background, state, condition and purpose of the hadiths

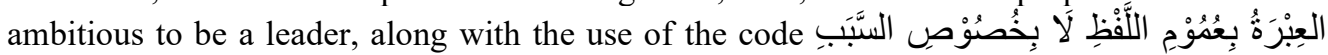
which means its common style is not a particular cause, then the understanding of the hadiths of ambition to be a leader is unworthy of a position especially as a leader filled by men of uncredibility in holding a trust given without bound by a given place, time, and condition.

\subsection{Differentiating between changing means and fixed targets}

In the previous discussion, it has been mentioned in terms of the so-called hadiths of ambition of leadership. Based on the discussion, it is understandable that some of the changeable means in the hadiths were among those requesting the office, the necessity of requesting the office, the type of office accompanied by the one requesting the type of office, the justice of the one requesting the office in the lap, the motive for the request of office, the time, the place and condition of the request of the office and the subjective view of the credibility of the party requesting the office. These changes are unchangeable, and they are not the permanent goal of the hadith [34].

By separating the changeable means, it has been found that the everlasting purpose of hadiths' ambition to be a leader isa lack of negative gluttony or ambition to a position and is unworthy to occupy any more office as a leader than only those who were credible in that 
office. Thus, in the present era of various conscription systems, the requirement of office may be possible as long as it does not conflict with the eternal purpose of hadits-hadith.

\subsection{Ensuring the meaning of the term within the hadith}

In the carefully researched hadiths, the author will confirm two words that have a

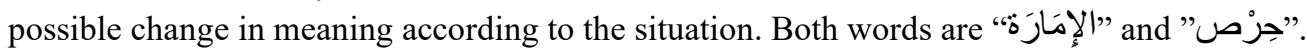

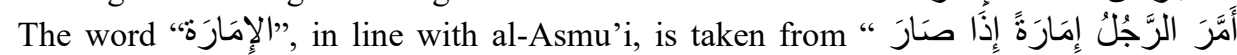

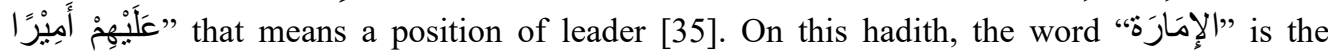
highest rank of the khalifah and the lower rank of leadership over parts of the region [36]. While the word "جِ"

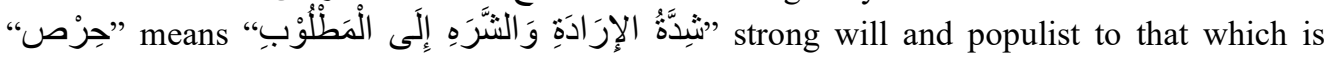

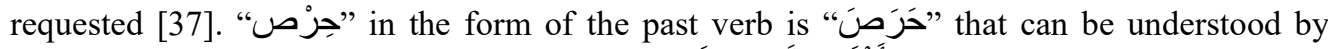

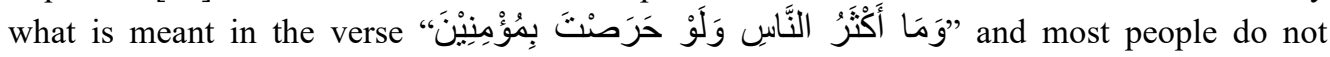

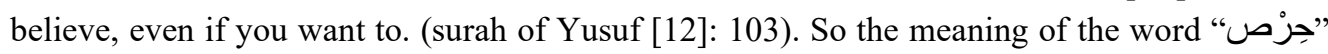
is wanting something that is in this case a post. This is accompanied by earnest effort to dismantle the office [38].

Thus, requesting an office of leader or any other office is forbidden, whether it be only as a wish, demand comes to the end of ambition to obtain it with a craving for it and every effort put forth to obtain it. Such meaning is excluded if the incumbent is not simply to serve his superior and not for his own benefit or class, but is the real cause of public good; If it would have brought about a good effect to be occupied by the person requesting the office; If during the application of an office comes not only from the applicant alone, but instead of an offer or an opening that can be taken for the purpose of common good; When coupled with the ability and ability to assume the office in a proper way and not in a prideful manner.

In requesting offices asa leader or any other office may require an office if the other (voter or superior) has not known the excess of the incumbent or if the motivation is only for the public good or if the office is in an unfavorable or non-committed environment to implementing laws, existing customs and structures; Offices as leaders or other offices are not worthy of being filled by uncredible persons in carrying out positions given either with or without asking for or ambition during a lack of gluttism or negative ambition.

Requesting the office of leader or any other office is forbidden to those who on behalf of the administration are unable to assume the office properly. That is the party that will not be helped in the performance of his office. Nevertheless, it does not necessarily have consequences to justice in taking the desired office; Occupying an office given without being asked is of no consequence on not receiving help in the resulting position.

\section{Contextual Meanings of the Hadith to Pancasila Democracy}

There are criteria for democracy, especially pancasila democracy which is impossible without any attempts to achieve it. Among them is the optative criteria, which is that democracy must achieve objectives for the good of mankind. It is also a formal criterary for which the democratic qualification involves the election of a people's and or a government's 
representative. And there are many other criteria. In the end, it was pancasila democracy, which gave people sovereignty, that needed the mechanism to achieve that.

Besides, when viewed by the definition of "political" according to the f. isjwara is one of the struggles to gain power or as a kind of exercise of power, democracy as part of a political system has attached itself to the identity of its system. Because of the formal criteria for pancasila democracy, in this case, there is a formal system of elections.

From these descriptions, the structure of modern societies in the democratic world does allow individuals who are very ambitious or even very ambitious to occupy leadership positions. Even so, in a democracy it does require efforts aimed at the welfare of the people. But instead, there are those who are resorting to those efforts to succession in ways that don't conform to rules and norms, such as the black campaign, the money campaign, lifting Sara's element, telling lies, telling lies around society.

There is no way a couple can be set apart without the support that is obtained from the people or the representation of the people. Because people in a democracy are basically the holders of real power. And so, essentially, a couple candidate is a mandate from the people. This if associated with the existing contextual meaning of the hadith, then this kind of nomination is not contextual. In view of the direction of Surah Yusuf verse 55 that the application of an office came not only from the applicant alone but from an offer or a position that could be taken with the express purpose of common good. In this case, in the Indonesian pancasila democracy system, the job is provided by support, whether by the people or by representation of the people (the political party) itself, whether by asking for it.

Though the aforementioned hadis الَّ تَنَأَلْ الإِمَارَة makes mention that, requesting a position as leader or any other office is forbidden, whether it is up to desire, the request comes to the ambition of obtaining it with a will that is passionate in its service with every effort that is being made to obtain it. Yet, if you look a little deeper, the mechanism of nomination for a candidate for leader in pancasila democracy is only valid, if it qualifies at least for popular support. This, therefore, constitutes an act of support, not merely to solicit support.

To understand this, as proof of its application, an actual individual candidate had occurred at the time of the removal of Abu Bakr as caliph. The day after the prophet's death, the Ansar initiates a major discussion in Thaqifah Bani Sa'idah. In such meetings the Khazraj clan designated Sa'd bin 'Ubadah as the caliph. While the Ansar people are still gathered in Thaqifah Bani Sa'idah, other muslims such as 'Umar and Abu 'Ubaidah bin Jarrah are still busy talking about the Prophet's death. While Abu bakr, 'Ali and the Prophet's family were busy making preparations for the prophet's funeral.

In these circumstances, 'Umar began thinking about muslims after the Prophet's death. So 'Umar immediately asked Abu 'Ubaidah to be willing to give way, but he refused because he felt that Abu Bakr was more suitable to replace the prophet. At the same time, news of the Ansar meeting in Thaqifah Bani Sa'idah is being heard today to 'Umar and Abu 'Ubaidah's ears. So 'Umar immediately sent someone to meet Abu Bakr, but he refused to go into the Prophet's funeral affairs. Then 'Umar told the messenger to go back to Abu Bakr with the message that Abu Bakr had something important to attend to. So Abu Bakr came in a state of wonder. By listening to 'Umar, Abu Bakr, 'Umar and Abu 'Ubaidah are departing for Thaqifah Bani Sa'idah.

Immediately, one of the Ansar parties stood up and delivered a sermon. The sermon revealed that, the Ansar felt the Muhajirin would seize their rights. However, after going through differences in perception and arguments, the Ansar also 'Umar agreed to revise Abu Bakr as a caliph. 
From the historical nomination of $\mathrm{Abu} \mathrm{Bakr}$, it is understandable that support of the people to be declared for his candidacy, should be carried out on the basis of voter recognition and propriety. This is what happened in Thaqifah Bani Sa'idah at the time. Where, at the moment of each party, the argument was thrown out. They were presented, though not the primary objective, as part of the finding support for the current caliph candidates. So it provides literary support and is based on awareness to assimilate bakr ash.

A candidate, therefore, is not in principle to satisfy the interests of any group or individual in view of the need for minimal support. This is what is in Pancasila Democracy as regulated in Undang-undang no. 10 year 2016 chapter 41 verse (2).

When it comes to the question of capability, it is really subjective. This is because the Prophet passed the plea 'Uthman bin abi al-'As and rejected the plea 'Abdurrahman bin Samurah and Abu Dharr based on the criteria of leadership on them. This is in line with historical evidence that 'Abdurrahman ibn Samurah who at the time of the Prophet was forbidden to occupy a position, but in the days of the caliph 'Uthman, he was made head of the region of as-Sijistan. Based on the subjectivity of a candidate's level of ability, the pancasila democratic system, embodied in Undang-undang no. 10 year 2016, article 7 of the verse (2), redefined in article 45 of the verse (2), sets certain basic criteria for ability that if met, is said to be worthy of leadership.

Not only should a leader's candidate have a good impact with talent, but that another leader's candidate should be running for office, not in a prideful capacity. When it comes to something more general, actually ability, as explained, is abstract. So proud of yourself. Therefore, if it is not in the capacity of prideful pride but in the ability to carry out the impact is still lacking, then this is what the meaning of hadith is: "requesting the office of leader or any other office is forbidden to those on the performance of the office who are unable to carry out the office well. That is the party that will not be helped in the performance of his office. Nevertheless, it does not necessarily have consequences to his justice in taking the desired office." Thus the candidate is

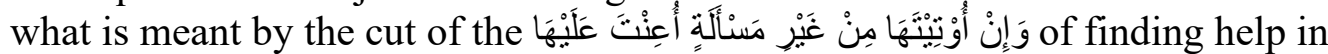
that position as long as it does not conflict with the other meanings of the hadiths of ambitious to be a leader.

Electoral leadership aims to safeguard people's sovereignty. There is no way people will vote consciously and rationally if they do not understand the leading candidates. This coincides with Surah Yusuf verse 55 that at the time the prophet Yusuf was offered by the king to assist him in various areas, yet the prophet chose and asked to be appointed as treasurer. To reassure him of his choice, the prophet Yusuf came to know that he was in the best position to care for a treasurer, as the prophet Yusuf realized that he was a brilliant man once again having knowledge.

Indonesia is not a state of islamic faith in the implementation of its system, but a law state based on religious values. In fact, the fact that it was allowed to prove even necessary was a campaign process in a chain of leader-selection processes. As is the interpretation of Sayyid Quṭb against Surah Yusuf verse 55, that is, if application is not to a society of perfectly stable growth, structure, and commitment.

This goes hand in hand with the meaning of the hadiths of ambitious to assume the office of leader or any other office may allow to occupy an office if the other (voter or superior) has not known the other advantage of the government or if the motivation is only for the public good, in this case, an expression of public political education or if the office is in an 
environment that does not To agree or not to commit to implementing islamic laws, habits and structures.

As to the desired meaning of the hadith, motivation sides in carrying out the campaign become important. If underpinned the voraciation, then the motivation in the candidate campaign is to offer the vision, the mission, and the programs that will be implemented if elected, so that people can understand the candidates well. This kind of motivation conforms to the viewpoint of quraysh Prof. Shihab in interpreting surah Yusuf verses 55-56 as to the motivation of the campaign.

In this regard, the campaign in the hadiths' view of leadership should represent the values that are an indication of the real reason for public good, the good effects that would arise when occupied by certain prospective couples and the ability and ability to assume the office.

This is demonstrated by the contual meaning of the hadith of requesting the office of leader or any other office is prohibited unless the one requesting the office is not simply to serve its superior and not for its own benefit or class, but is also for the real cause of general good; Unless they are coupled with the ability and ability to assume a fine office and not in a prideful manner; And except that it would have a good effect to be taken upon the one asking for the office.

Even with the concepts of the campaign as presented, the value of ambition of one candidate remains a viable possibility. Because asking people for support to vote for and to support a prospective mate raises the desire to really get it. In this regard, just as the Prophet accepted the request of 'Uthman bin Abi al-'As and rejected the appeal 'Abdurrahman bin Aamurah and Abu Dharr based on the criteria of leadership's ability in themselves, the subjective value of each couple's candidate for intention and purpose strongly determined whether or not to campaign in the hadiths' vision of leadership.

It is just, to achieve a good goal, that peoples well-being needs to be ambitious, to achieve it. This coincides with the opinion Ibn Hajar al-'Asqalani in compromising the hadiths of ambition to be a leader in defiance that, the absence of aid (which is a consequence of soliciting office) for the relact and office hadith has absolutely no consequence to his justice in taking the required office. Moreover, as explained earlier, if that ambition does not contradict the contextual meaning of hadis-hadis ambition is not prohibited.

\section{Conclusions}

Asking the people to post sovereignty to run for leadership is forbidden, whether it be only desire, demand comes to ambition to obtain it with a will and every effort put forth to achieve it such a good campaign through any mechanism.

Such exemptions should be made to the benefit of the common people as part of the embodiment of political education to society; If support on the basis of such requests is obtained in ways that do not conflict with traditional religious norms and decency and are based on common-consciousness consciousness on the part of the electorate; If the nomination is accompanied by an awareness of a good impact with indications of ability and ability and the absence of a boast that the leader is occupied by the candidate; If there is a possibility of support that it will gain, it will only increase for a party that recognizes its capabilities and abilities in ways that conform to the norms of islamic religion in order to realize pancasila democratic values; If society as voters with the highest sovereignty in the country know for 
sure that the candidate to be elected is one who is able to occupy that office by accurately and competently delivering its vision, mission and programs, with the welfare of the people.

Asking the people for an office of sovereignty to run for leadership even without any efforts to achieve it is an act that would have no help unless otherwise contextual meaning the aforementioned hadit. However, it does not necessarily have consequences to his justice in taking the desired office.

Asking the people for the position of sovereignty to run as leaders by any means is to be allowed in a country that does not subscribe to the islamic system of rule as long as it does not conflict with the traditional islamic terms of teachings including the virtues of the prophet's hadith with general motivation.

Asking the people for the post of sovereignty to run as leaders in any way, as long as it does not conflict with the meaning of the hadis-hadis ambition to be a leader at the top, in spite of the inadequate ability to be a leader, will receive relief in performing his post. Incumbent by the people as incumbent on sovereignty as leader, without any effort to achieve it in any form, though he knowingly knows he will not be able to carry out the office granted to the party to get help. Requesting titles as leaders or other offices with every effort to obtain them that conflict with legal and religious norms will wreak havoc in the coming apocalypse.

Acknowledgements. This research supported by The Graduate School of Islamic Studies UIN Syarif Hidayatullah.

\section{References}

[1] Mufti, M.: Politik Islam Sejarah dan Pemikiran. pp. 48. Pustaka Setia, Bandung (2015)

[2] Ubaedillah, A. and Abdul Rozak.: Pendidikan Kewarga[negara]an (Civic Education) Demokrasi, Hak Asasi Manusia, dan Masyarakat Madani Edisi Revisi. pp. 68. Kencana Prenadamedia Group, Jakarta (2013)

[3] as-Suyūți.: Jam` al-Jawāmi` aw al-Jāmi` al-Kabir Li as-Suyūṭi. Vol. 1. al-Maktabah asySyāmilah, Version 2.11.0.0

[4] al-'Asqalāni, I. Ḥ.: Fatḥ al-Bāri syarḥ Șaḥiḥ al-Bukhāri. Book 35. pp. 432-436. Pustaka Azzam, Jakarta (2012)

[5] al-Bukhāri.: Shahih Al-Bukhari. Ensiklopedi Hadits 9 Imam. Version 3.0 Android

[6] Munawwir, A. W.: Kamus Al-Munawwir Arab-Indonesia Terlengkap. Second Edition. pp. 254. Pustaka Progressif, Surabaya (1997)

[7] an-Nawāwi.: at-Taqrib wa At-Taysir. pp. 26. Darul Kutub al-`Arabiy, Beirut (1985)

[8] Sadiah, D.: Metode Penelitian Dakwah Pendekatan Kualitatif dan Kuantitatif. pp. 20. Remaja Rosdakarya, Bandung (2015)

[9] Agustam.: Konsepsi dan Implementasi Demokrasi Pancasila Dalam Sistem Perpolitikan Di Indonesia. Vol. 7, No. 12, pp. 83. Jurnal TAPIs (2011)

[10] Ananingsih, S. W.: Tantangan Dalam Menangani Dugaan Praktik Politik Uang Pada Pilkada Serentak 2017. Vol. 45, No. 1, pp. 4-5. Jurnal Masalah-masalah Hukum (2016)

[11] Waluyo, T. J.: Partai Politik dan Pemilihan Kepala Daerah. Vol. 9, No. 1, pp. 53. Jurnal Demokrasi dan Otonomi Daerah (2011)

[12] Pujiningsih, S.: Kajian Yuridis Terhadap Calon Perseorangan Dalam Sistem Pemilihan Kepala Daerah Secara Langsung. Vol. 20, No. 2, pp. 102. Pena Jurnal Ilmu Pengetahuan dan Teknologi (2011)

[13] Sidiq, U.: Kepemimpinan dalam Islam: Kajian Tematik dalam Alquran dan Hadits. Vol. 12, No. 1, pp. 131-135. Dialogia: Jurnal Studi Alquran dan Hadis (2014) 
[14] Daswati.: Implementasi Peran Kepemimpinan dengan Gaya Kepemimpinan Menuju Kesuksesan Organisasi. Vol. 04, No. 01, pp. 50-52. Academica: Jurnal Ilmiah Ilmu Sosial dan Ilmu Politik Fisip Universitas Tadulako (2012)

[15] Waluyo, T. J.: Partai Politik dan Pemilihan Kepala Daerah. Vol. 9, No. 1, pp. 100. Jurnal Demokrasi dan Otonomi Daerah (2011)

[16] Muhsin, M.: Kritik Matan Hadis Studi Perbandingan antara Manhaj Muhaddithin Mutaqaddimin dan Muta'akhkhirin. pp. 83-85. PKBM "Ngudi Ilmu”, Magelang (2013)

[17] Ismail, S.: Hadis Nabi yang Tekstual dan Kontekstual. pp. 120-123. Bulan Bintang, Jakarta (1994)

[18] al-Qarḍawi, Y.: al-Madkhal li Dirāsah as-Sunnah an-Nabawiyyah. pp. 98-115. CV. Pustaka Setia, Bandung (2007)

[19] al-'Asqalāni, I. Ḥ.: Fatḥ al-Bāri syarḥ Șaḥiḥ al-Bukhāri. Book 35, pp. 110-113. Pustaka Azzam, Jakarta (2012)

[20] Quṭb, S.: Fi Zilāl al-Qur'ān. Vol. 6, pp. 78-81. Gema Insani Press, Jakarta (2003)

[21] Shihab, M. Q.: Tafsir al-Mishbah. Vol. 6, pp. 285-290. Lentera Hati, Tangerang Selatan (2009)

[22] Kathir, I.: Tafsir Lubāb at-Tafsir min Ibn Kašir. Vol. 4, pp. 381-382. Pustaka Imam Asy-syafi'i (2008)

[23] Shihab, M. Q.: Tafsir al-Mishbah. Vol. 6, pp. 285. Lentera Hati, Tangerang Selatan (2009) and Quṭb, S.: Fi Zilāl al-Qur'ān. Vol. 6, pp. 80. Gema Insani Press, Jakarta (2003)

[24] al-Qurțubi.: al-Jāmi‘ li Ahkām al-Qur’ān. Vol.15, pp. 90-93. Pustaka Azzam, Jakarta (2009)

[25] Muhsin, M.: Pengantar Studi Kompleksitas Hadis. pp. 75-77. FUD Press, Serang (2013)

[26] an-Nawāwi.: Șahịh Muslim bi Syarh an-Nawāwi. Vol. 12, pp. 230-233. Pustaka Azzam, Jakarta (2011)

[27] Amiruddin, Z.: Ushul Fiqih. pp. 80. Teras, Yogyakarta (2009)

[28] al-'Ibād, A. M.: Syarh Sunan Abi Dāud. Vol. 14. al-Maktabah asy-Syāmilah Version 2.11.0.0

[29] 'Ițr, N.: Manhaj an-Naqd fi 'Ulūm al-Ḥadis. pp. 150-151. Remaja Rosdakarya, Bandung (2014)

[30] Khon, A. M.: Takhrij dan Metode Memahami Hadis. pp. 76. Amzah, Jakarta (2014)

[31] al-Mubārakfuri.: ar-Rahiq al-Makhtūm Bahs̉ Fi Sirah an-Nabawiyyah 'alā Șāhibihā Afḍal aṣȘalāh wa as-Salām. pp. 99-101. Pustaka al-Kautsar, Jakarta (2001)

[32] al-Mizi, Y.: Tahżib al-Kamāl. Vol. 19, pp. 161. al-Maktabah asy-Syāmilah version 2.11.0.0

[33] aș-Șan'āni, M.: Subul as-Salām. Vol. 1, pp. 170. al-Maktabah asy-Syāmilah version 2.11.0.0

[34] Muhsin, M.: Pengantar Studi Kompleksitas Hadis. pp. 58. FUD Press, Serang (2013)

[35] al-Azhari: Tahżib al-Lugah. Vol. 5, pp. 120. al-Maktabah asy-Syāmilah, version 2.11.0.0

[36] al-‘Asqalāni, I. Ḥ.: Fatḥ al-Bāri syarḥ Șaḥiḥ al-Bukhāri. Book 35, pp. 250-252. Pustaka Azzam, Jakarta (2012)

[37] al-Afriqi, M.: Lisān al-‘Arab. Vol. 7, pp. 133. al-Maktabah asy-Syāmilah, version 2.11.0.0

[38] al-'Ibād, A. M.: Syarḥ Sunan Abi Dāud. Vol. 14, pp. 230. al-Maktabah asy-Syāmilah, Version 2.11.0.0.

[39] Kartono, K.: Pemimpin dan Kepemimpinan. pp. 50. Rajagrafindo Persada, Depok (2013) 